\title{
Is Alpha Minus Beta A Simple Rule for A Smart Beta Strategy?
}

\author{
Darrol J. Stanley \\ Pepperdine Graziadio Business School \\ Michael D. Kinsman \\ Pepperdine Graziadio Business School \\ Andreas Simon \\ Pepperdine Graziadio Business School
}

Thematic investment portfolios have been of interest to portfolio managers. They can take on a variety of names including Smart Beta. One such model was suggested by Minami and Wakatsaki. They suggested an investment rule of Alpha Minus Beta as a good method to build a factor tilt portfolio which is efficient in an absolute risk-return space. This paper addresses their model by empirically examining market data. The S\&P 1500 was segmented into quintiles based on Alpha Minus Beta for a fifteen year period. The suggested model had value as the Coefficient of Variation was favorable compared to the index.

Keywords: Smart Beta, Alpha, Beta, Alpha Minus Beta, Factor Tilt, Market Efficiency

\section{INTRODUCTION}

Among the most widely believed paradigms in finance is the contention that the stock market is efficient. Eugene F. Fama espoused this paradigm, The Efficient Market Hypothesis (EMH), while a doctoral student at Chicago. The core concept is simple. Stock prices change due to the appearance of new and unanticipated information. Since this information is revealed randomly, stock prices at all times are correctly set, which is the finance definition of "efficient."

The concept of an efficient market is still paramount in investment theory, although strict interpretation of it has been challenged as time has passed. Fama (1970) noted that in an efficient market any new information would be immediately and fully reflected in equity prices. Therefore, a financial market quickly, if not instantaneously, discounts all available information, and investors should expect an asset's price to reflect its true fundamental value at all times. Bruno Solnik (1996) noted that since fundamental value is unknown, the only way to test for market efficiency is to detect whether some specific news is not yet incorporated in the asset price and could therefore be used to make abnormal profit.

Those who challenge EMH suggest that there exists available public information that can be more effectively incorporated in the asset price and therefore be used to make abnormal profit. This group includes most of the world's investment managers. 


\section{MARKET EFFICIENCY}

It is essential to understand the environment in which securities are priced. The signal question is how effectively investors' expectations are incorporated into security pricing. Are investors' expectations for a particular security quickly and accurately reflected in the price of the security? This is the concept of market efficiency.

In an efficient market, the current prices of securities represent unbiased estimates of the "fair," "intrinsic," "real," "fair market," "sound," and "true" value of the securities. According to Capital Market Theory, if all securities are correctly valued (by whatever term), investors will earn a "normal return" on their investment appropriate to the level of risk borne by the investor. This "normal return" will occur regardless of which securities are purchased. Thus, in a perfectly efficient market in equilibrium all securities are correctly priced, and there are no under- or over- valued securities.

The degree to which a market is efficient has profound implications for investors. In an efficient market, the time, money, effort, required knowledge, and anxiety required to engage in security analysis become meaningless on an individual basis.

The central theorem of the EMH is that the security market participants are competent and wellinformed. It is the competition among these very astute market participants which results in security prices being fairly and correctly priced. These market participants immediately "compete away" any chance to earn an abnormal profit.

\section{EFFICIENT MARKET HYPOTHESIS}

The framework for a discussion of the Efficient Market Hypothesis (EMH) is generally centered around Eugene Fama's May 1970 Journal of Finance paper "Efficient Capital Markets: A Review of Theory and Empirical Work."

Fama defined efficient markets in terms of a "fair game" where security prices "fully reflect" all the information available. Consequently, if a market is efficient, individuals cannot consistently receive abnormal risk-adjusted returns in that market. In the framework of the Capital Asset Pricing Model, the expected value of ex-ante alpha (expected excess profits) must be zero. This implies that the complete measurement of risk is contained in the beta of the security.

Fama suggested that potentially efficient markets can be divided into three categories, based on their strength of efficiency:

1. Strong-Form. The strong-form Efficient Markets Hypothesis (EMH) represents the most extreme case of market efficiency. Strong-form proposes that security prices fully reflect all information, whether public or private. Fama himself thought that this form was an extreme one that, if ever adequately tested, would prove false.

2. Semi-Strong Form. The semi-strong form EMH asserts that security prices rapidly and correctly adjust to the release of publicly available information. Thus, under the semi-strong form, current prices fully reflect not only all past price data but all other data as well. Hence, any and all information that is available to the public should be quickly, if not instantaneously, reflected in security prices so that investors cannot consistently earn abnormal returns by acting on such public information.

3. Weak-Form. In the weak-form EMH, the type of information being considered is restricted exclusively to historical price data. If the weak-form EMH is correct, investors should not be able to earn abnormal profits by simply observing the historical prices of securities. WeakForm efficiency is, in fact, a special case of Semi-Strong form efficiency.

There are an extensive number of empirical studies of the EMH. It is beyond the scope of this paper to conduct even a casual review of those studies. Suffice it to say, researchers have tested the EMH due to its signal importance in financial literature. Their combined results indicate that the EMH, as postulated by Fama, is overwhelmingly supported. This is especially true in dealing with the weak and semi-strong 
versions of the hypothesis. The difficulty of obtaining data on undisclosed sources of information makes it difficult to research the strong-form hypothesis.

However, even in face of this consensus, there are a growing number of researchers who question the EMH. Among them, Robert Haugen argues in multiple books that the EMH is a paradigm that is at the extreme end of the spectrum. He has made a serious case for recognizing that the market overreacts to past records of success and failure with resulting incorrect or imprecise security prices. (Haugen (1999) New Finance p. ix)

Other researchers hold even more extreme views, holding that the market is in chaos (which also implies you cannot beat the index as well). Finally, there is a small but growing group that believes the American stock market is now (perhaps again) manipulated. $\backslash$

\section{SMART BETA}

This paper is focused on one aspect of the Capital Market Theory Spectrum: Alpha minus Beta as a viable subset for the construction of a Smart Beta portfolio. There is always confusion as to what is the definition of a smart beta portfolio. In effect, smart beta is a combination of efficient-market hypothesis and value investing. Smart beta defines a set of investment strategies that emphasize the use of alternative index construction rules to traditional market capitalization-based indices. In this sense, the concept of "Smart" refers to the use of an alternative methodology rather than following an index's size-based (market-cap) allocations. A smart beta investment strategy is designed to add value by strategically choosing, weighting and rebalancing the companies built into an index based upon objective factors.

Thus smart beta strategies are an attempt to bridge the gap between active and passive investing. Smart beta strategies have become a popular alternative for investors. They attempt to utilize a systematic, rules-based approach to portfolio construction to capture market inefficiencies, and can take multiple forms. There are five broad classifications: (1) Equal-Weight; (2) Low-Volatility; (3) Momentum; (4) Quality; and (5) Fundamental. It should be noted that there are more than 845 strategic beta strategies in the Morningstar universe with various attempts to capture market inefficiencies.

It is not the intent of this paper to justify, or even examine the validity, of smart beta strategies. There are numerous studies, both academic and practitioner, devoted to such an examination. Figure 1 is one review of smart beta strategies developed by Charles Schwab \& Company in February of 2018 covering the period 2009 through 2017. It comes from Schwab Center for Financial Research with data provided by Morningstar Direct. Data used from January 1, 2007 through December 31, 2017. Strategy performance represented by annual total returns for the following indexes: Market Capitalization (Market Cap) - S\&P 500; Fundamental - Russell RAFI U.S. Large Company; Equal Weight - S\&P 500 Equal Weighted; Momentum - MSCI USA Momentum; Low Volatility - S\&P 500 Low Volatility; Quality Russell 1000 Quality Factor. Indexes are unmanaged, do not incur fees or expenses, and cannot be invested in directly. Schwab suggests that users see disclosures for more information about the market indexes, and reminds us that past performance is not indicative of future results.

Portfolio managers have found it very difficult to outperform indices consistently on a risk-adjusted basis. This has been especially true for the S\&P 500 index (large-cap). Stated another way, investors have not been able to capture positive "excess alpha" in their stock selection process. 
FIGURE 1

SCHWAB ASSET CLASS QUILT

\section{Schwab Asset Class Quiltº}

\section{Smart Beta Strategies, Year-Over-Year Results}

\begin{tabular}{|c|c|c|c|c|c|c|c|c|c|}
\hline 2008 & 2009 & 2010 & 2011 & 2012 & 2013 & 2014 & 2015 & 2016 & 2017 \\
\hline $\begin{array}{l}\text { Low } \\
\text { Volatility } \\
-21.4 \%\end{array}$ & $\begin{array}{l}\text { Equal } \\
\text { Weight } \\
4635\end{array}$ & $\begin{array}{l}\text { Equal } \\
\text { Weght } \\
219 \%\end{array}$ & $\begin{array}{l}\text { Low } \\
\text { volatily } \\
148 \%\end{array}$ & $\begin{array}{l}\text { Eqaal } \\
\text { Welght } \\
17346\end{array}$ & $\begin{array}{l}\text { Equal } \\
\text { Weight } \\
36 \mathrm{ks}\end{array}$ & $\begin{array}{l}\text { Low } \\
\text { volatilty } \\
175 \% 6\end{array}$ & $\begin{array}{c}\text { Momen- } \\
\text { tum } \\
87 \%\end{array}$ & $\begin{array}{l}\text { Funda- } \\
\text { mental } \\
16.3 \%\end{array}$ & $\begin{array}{c}\text { Momen- } \\
\text { tum } \\
374 \%\end{array}$ \\
\hline $\begin{array}{l}\text { Cualty } \\
-31.1 \%\end{array}$ & $\begin{array}{l}\text { Funda- } \\
\text { mertal } \\
33.1 \%\end{array}$ & $\begin{array}{l}\text { Fundar } \\
\text { merkal } \\
1795\end{array}$ & $\begin{array}{l}\text { Cualty } \\
8.5 \%\end{array}$ & $\begin{array}{l}\text { Funda } \\
\text { mental } \\
16.3 \%\end{array}$ & $\begin{array}{l}\text { Funda: } \\
\text { montal } \\
34.3 \%\end{array}$ & $\begin{array}{l}\text { Ecual } \\
\text { Weight } \\
14.9 \%\end{array}$ & $\begin{array}{l}\text { Low } \\
\text { Volatitity } \\
43 \%\end{array}$ & $\begin{array}{l}\text { Egual } \\
\text { wobit } \\
148 \text { is }\end{array}$ & $\begin{array}{l}\text { Qualty } \\
28.15 s\end{array}$ \\
\hline $\begin{array}{l}\text { Funds- } \\
\text { mental } \\
-34.7 \% 6\end{array}$ & $\begin{array}{l}\text { Quality } \\
26746\end{array}$ & $\begin{array}{c}\text { Momen- } \\
\text { tum } \\
178 \%\end{array}$ & $\begin{array}{c}\text { Momen- } \\
\text { tum } \\
5.5 \%\end{array}$ & $\begin{array}{l}\text { Qunlty } \\
16.1 \% 6\end{array}$ & $\begin{array}{c}\text { Momen- } \\
\text { tum } \\
34.0 \% 6\end{array}$ & $\begin{array}{c}\text { Momen } \\
\text { tum } \\
14.2 \%\end{array}$ & $\begin{array}{c}\text { Qulty } \\
2.1 \%\end{array}$ & $\begin{array}{l}\text { Market } \\
\text { Cap } \\
120 \% 5\end{array}$ & $\begin{array}{l}\text { Mankat } \\
\text { Cap } \\
21.8 \%\end{array}$ \\
\hline $\begin{array}{c}\text { Market } \\
\text { Cap } \\
-367 \%\end{array}$ & $\begin{array}{c}\text { Mapet } \\
\text { Cap } \\
265 \%\end{array}$ & $\begin{array}{c}\text { Maket } \\
\text { Cap } \\
15.16\end{array}$ & $\begin{array}{l}\text { Funds- } \\
\text { mental } \\
2905\end{array}$ & $\begin{array}{l}\text { Markes } \\
\text { Cap } \\
160 \%\end{array}$ & $\begin{array}{c}\text { Mabet } \\
\text { Cap } \\
32.4 \% 6\end{array}$ & $\begin{array}{l}\text { Market } \\
\text { Cap } \\
137 \%\end{array}$ & $\begin{array}{l}\text { Market } \\
\text { Cap } \\
1 . A \%\end{array}$ & $\begin{array}{l}\text { Cusity } \\
10 \pi \%\end{array}$ & $\begin{array}{l}\text { Equal } \\
\text { whight } \\
189 \text { s }\end{array}$ \\
\hline $\begin{array}{l}\text { fcual } \\
\text { Woight } \\
-39795\end{array}$ & $\begin{array}{l}\text { Low } \\
\text { volaairy } \\
19.2 \%\end{array}$ & $\begin{array}{l}\text { Quality } \\
14.5 \%\end{array}$ & $\begin{array}{c}\text { Market } \\
\text { Cap } \\
21 \% 6\end{array}$ & $\begin{array}{c}\text { Momen- } \\
\text { bum } \\
14.3 \%\end{array}$ & $\begin{array}{l}\text { Qualiny } \\
31.7 \%\end{array}$ & $\begin{array}{l}\text { Qualty } \\
13.3 \%\end{array}$ & $\begin{array}{l}\text { Equal } \\
\text { Weight } \\
-2.2 \%\end{array}$ & $\begin{array}{l}\text { Low } \\
\text { Volatilty } \\
10,4 \%\end{array}$ & $\begin{array}{l}\text { Low } \\
\text { Volatilty } \\
17.4 \%\end{array}$ \\
\hline $\begin{array}{l}\text { Momen- } \\
\text { tum } \\
-41.1 \%\end{array}$ & $\begin{array}{l}\text { Momen- } \\
\text { tum } \\
17.1 \% 6\end{array}$ & $\begin{array}{l}\text { Low } \\
\text { volailify } \\
13.4 \%\end{array}$ & $\begin{array}{l}\text { Equal } \\
\text { Weight } \\
-0.1 \%\end{array}$ & $\begin{array}{l}\text { Low } \\
\text { volscity } \\
10.3 \%\end{array}$ & $\begin{array}{l}\text { Low } \\
\text { volstity } \\
23.6 \%\end{array}$ & $\begin{array}{l}\text { Funda- } \\
\text { mental } \\
12.3 \%\end{array}$ & $\begin{array}{l}\text { Funda: } \\
\text { mental } \\
-30 \% 6\end{array}$ & $\begin{array}{c}\text { Momen- } \\
\text { tum } \\
4.6 \%\end{array}$ & $\begin{array}{l}\text { Funda- } \\
\text { mental } \\
173 \% 6\end{array}$ \\
\hline
\end{tabular}

\section{ALPHA MINUS BETA}

Finding "excess alpha" has been the goal of portfolio managers since investment management began. Given this "Holy Grail" orientation, it seems only logical to examine the concept of constructing a portfolio in which "excess alpha" dominates.

This smart beta study examines this statistical relationship in the development of both the alpha and beta of the standard least-square regression. Specifically, each stock in the study has been regressed against the S\&P 500 in a sixty month relationship of percentage price change of the stock versus the index.

The resulting equation produces an alpha (ALP) and the beta (BTA) of the resulting regression line. Beta is generally thought of as a measure of risk in a diversified portfolio, and alpha generally reflects things unexplained by the expected risk (versus the market) of the portfolio or security.

We then calculate DIF, the difference between ALP and BTA. All stocks are then arrayed based on DIF, from the highest positive DIF to the lowest negative DIF. The basic idea being that this is a form of "free lunch." This clearly enhanced excess return might result in a superior risk-adjusted smart beta portfolio. Such a portfolio could stand alone (passive portfolio) or segmented by other factors (active portfolio). 


\section{RESEARCH HYPOTHESES}

Five research hypotheses, numbered Hypothesis One through Hypothesis Five, are explored in this paper.

\section{Research Hypothesis One}

By segmenting the S\&P 1500 into ALP-BTA quintiles (rebalanced on a monthly basis), the top ALPBTA quintile will, on a risk-adjusted basis before transaction costs, outperform both the S\&P 1500 (Equally-Weighted) as well as the bottom ALP-BTA based on the portfolio's Coefficient of Variation (CV). Thus, this paper is conducting a test of the semi-strong form of the EMH.

The research period is the fifteen years from January 1, 2003 through December 31, 2017. The CV analysis for hypothesis testing was applied against intermediate or yearly period data. While the statistics for a total run period seldom vary for the intermediate period, the intermediate yearly periods are far more important to investment managers due to the drawdown problem in investment management. Drawdown refers to the reduction in asset value in any one period. Investment managers to do not want to have any one period with a significant drawdown of value, compared to the benchmark, even if the strategy is favorable over the long-run.

Dividing the S\&P 1500 into five portfolios based on ALP-BTA alone was done to assure efficient diversification. While industry and/or sector groups should be accounted for in normal portfolio construction, the five large (300) security portfolios obtained from quintiles of the S\&P 1500 mitigates this problem.

\section{Research Hypotheses Two Through five}

The Top ALP-BTA quintile will be studied using four different factor models (labelled Research Hypothesis Two through Research Hypothesis Five) and breaking the top quintile into five 60 security portfolios. The research hypothesis for these four "factor models" is that the top portfolio for each factor model will outperform the lower portfolios using that factor model, the quintile universe and the S\&P 1500 universe:

\section{Research Hypothesis Two}

Price Momentum (PRM) has been seen as a predictor of near-term future returns, based on historical price changes. A regression analysis was developed to analyze the correlation between relative future returns and past price gain descriptors for the past month, quarter, and year. The price momentum (PRM) figure utilized is computed from the following equation. This data is a percentile, with 100 being the top percentile.

$\mathrm{PRM}=\mathrm{PGY}-\mathrm{PGQ}-(3 * \mathrm{PGN})$

where: $P R M=$ Total Adjusted cumulative price return

$\mathrm{PGY}=$ Total price return for the past twelve months

$\mathrm{PGQ}=$ Total price return for the past three months

$\mathrm{PGN}=$ Total price return for the past month

\section{Research Hypothesis Three}

Operating Earnings Yield (OEY) is calculated by dividing the 12 month pro-forma operating earnings per share by the share price. This pro-forma earnings number includes the past three historical quarters plus the consensus estimate for the next quarter. This calculation is the inverse of the price to earnings $(\mathrm{PE})$ ratio. The $\mathrm{PE}$ ratio is often used as a measure of value. 


\section{Research Hypothesis Four}

Earnings Momentum (EMO) measures the acceleration or deceleration in earnings growth for the 12 months based on the operating EPS series (OEY) ending in each of the last four quarters plus the consensus estimate for the current quarter. This data is a percentile, with 100 being the top percentile.

\section{Research Hypothesis Five}

Value Momentum (VMO) combines acceleration of earnings growth with relative value and price momentum. Earnings Momentum (EMO), Standard Unexpected Earnings and the one month change in the consensus earnings estimates for FY1 and FY2 are combined with earnings yield (OEY) (based on operating earnings for the last three quarters and the current quarter estimate) and Price Momentum (PRM).

\section{DATA AND METHODOLOGY}

This paper will explore the total portfolio's return on a risk-adjusted basis using the hypotheses listed above. Ford Equity Research of San Diego, a data vendor with proprietary models for investment managers globally, supplied the data for this study. Ford Equity Research is affiliated with Mergent, a subsidiary of the London Stock Exchange, through stock ownership.

A review of the data and methods used by Ford Equity Research is constructed such that the three most common biases in investment data (no look-ahead bias; no restatement bias; and survivorship bias) were eliminated.

Ford Equity Research, likewise, provided all variables utilized in this study. Total return includes both price changes and dividends in the appropriate period based on their ex-dividend date. Returns were computed on a geometric basis as were the standard deviations. These methods are in conformity with accepted professional investment standards.

All returns, including the index, were calculated on a monthly basis, were computed equallyweighted, and were selected from the S\&P 1500 Index.

The selection of the sample size is a concern for all researchers. The selection of five portfolios of 300 stocks each reduced the impact of industry concentration in this study, as is especially important in short time frame studies. Ideally, the number of stocks from any specific industry should be in line with the benchmark index and the selected portfolio should be of the same industry weightings as the benchmark index. Such back-testing requires significant manual analysis and unfortunately introduces questions of inappropriate manipulation of results.

\section{DATA RESULTS AND ANALYIS}

The results of the investigation can be found in the five tables of Appendix I, each run using monthly data before transaction costs. It was decided a-priori that the study could be re-run if the results warranted it for turnover and transaction costs.

Table 1 presents the results of Hypothesis One on a risk-adjusted basis (ALP-BTA). Hypothesis 1 was confirmed. The top quintile based on the ALP-BTA statistic outperformed the bottom quintile as well as the universe. The top quintile had a CV of 1.25 while the bottom quintile had a CV of 2.30 with a correlation of +0.77 . The top quintile outperformed the universe with a $\mathrm{CV}$ of 1.40 . The correlation between the top quintile and the universe was +0.93 . Thus, this portfolio was superior to the universe with less than a perfectly positive correlation. 
TABLE 1

S\&P 1500 ALP-BTA QUINTILES

\begin{tabular}{|c|c|c|c|c|c|c|}
\hline \multicolumn{7}{|c|}{ Intermediate Period } \\
\hline Year & $\begin{array}{l}\text { Sector } 1 \\
\text { Perf }\end{array}$ & $\begin{array}{c}\text { Sector } 2 \\
\text { Perf }\end{array}$ & $\begin{array}{c}\text { Sector } 3 \\
\text { Perf }\end{array}$ & $\begin{array}{c}\text { Sector } 4 \\
\text { Perf }\end{array}$ & $\begin{array}{c}\text { Sector } 5 \\
\text { Perf }\end{array}$ & $\begin{array}{l}\text { Comp } \\
\text { Universe } \\
\text { Perf }\end{array}$ \\
\hline 2003 & 46.5 & 37.9 & 39.8 & 37.9 & 60.4 & 44.4 \\
\hline 2004 & 21.4 & 21.1 & 19.2 & 16.3 & 15.8 & 18.7 \\
\hline 2005 & 10.9 & 11.6 & 10.0 & 4.2 & 1.0 & 7.5 \\
\hline 2006 & 8.6 & 16.5 & 20.8 & 16.7 & 19.1 & 16.3 \\
\hline 2007 & 8.6 & 1.7 & 0.5 & -6.5 & -12.0 & -1.8 \\
\hline 2008 & -42.1 & -28.3 & -28.4 & -35.8 & -46.3 & -36.4 \\
\hline 2009 & 31.3 & 27.0 & 31.4 & 47.8 & 101.1 & 46.7 \\
\hline 2010 & 25.1 & 24.3 & 24.5 & 31.3 & 30.8 & 27.4 \\
\hline 2011 & 5.0 & 2.9 & 0.2 & -3.6 & -11.6 & -1.5 \\
\hline 2012 & 13.5 & 16.9 & 15.9 & 16.5 & 26.3 & 17.8 \\
\hline 2013 & 38.8 & 33.4 & 37.3 & 39.9 & 46.3 & 39.1 \\
\hline 2014 & 14.3 & 11.5 & 11.3 & 9.9 & -1.3 & 9.0 \\
\hline 2015 & 8.1 & 2.6 & -3.7 & -4.4 & -20.5 & -3.8 \\
\hline 2016 & 10.2 & 20.7 & 22.9 & 27.6 & 38.3 & 23.9 \\
\hline 2017 & 19.0 & 17.6 & 14.3 & 16.4 & 3.0 & 14.0 \\
\hline Total & 492.6 & 551.9 & 525.6 & 456.2 & 407.5 & 499.1 \\
\hline Annual & 12.6 & 13.3 & 13.0 & 12.1 & 11.4 & 12.7 \\
\hline Annual STD & 15.8 & 14.5 & 16.0 & 19.0 & 26.2 & 17.8 \\
\hline $\mathrm{CV}$ & 1.25 & 1.09 & 1.23 & 1.57 & 2.30 & 1.40 \\
\hline
\end{tabular}

Correlation Matrix

\begin{tabular}{lrrrrrr}
\hline & $Q 1$ & \multicolumn{1}{c}{$Q 2$} & $Q 3$ & $Q 4$ & $Q 5$ & Universe \\
\hline Q1 & 1 & & & & & \\
Q2 & 0.957774 & 1 & & & & \\
Q3 & 0.924128 & 0.988018 & 1 & & & \\
Q4 & 0.890903 & 0.95749 & 0.972532 & 1 & & \\
Q5 & 0.774488 & 0.844259 & 0.886472 & 0.940748 & 1 & \\
Universe & 0.925701 & 0.972832 & 0.983578 & 0.990675 & 0.942916 & 1 \\
\hline
\end{tabular}


Table 2 presents the results on a risk-adjusted basis for Hypothesis Two (PRM) and shows that Hypothesis 2 was rejected. The top quintile of the top S\&P 1500 quintile based on the ALP-BTA statistic underperformed both the bottom quintile as well as the universe. The top PRM quintile had a CV of 1.78 clearly inferior to the bottom quintile with a CV of 1.22 with a correlation of +0.90 . The top quintile underperformed the universe (1.78 vs 1.25$)$ with a correlation of +0.97 . Surprisingly, the bottom PRM quintile $\mathrm{CV}$ outperformed the $\mathrm{CV}$ of the universe $(1.22 \mathrm{v}$. 1.25$)$ with a correlation of +0.96 .

TABLE 2

PRM

\begin{tabular}{ccccccc}
\hline & $\begin{array}{c}\text { Sector 1 } \\
\text { Year }\end{array}$ & $\begin{array}{c}\text { Sector 2 } \\
\text { Perf }\end{array}$ & $\begin{array}{c}\text { Sector 3 } \\
\text { Perf }\end{array}$ & $\begin{array}{c}\text { Sector 4 } \\
\text { Perf }\end{array}$ & $\begin{array}{c}\text { Sector 5 } \\
\text { Perf }\end{array}$ & $\begin{array}{c}\text { Comp Universe } \\
\text { Perf }\end{array}$ \\
\hline 2003 & 48.8 & 40.3 & 41.4 & 43.8 & 57.0 & 46.5 \\
2004 & 16.0 & 17.7 & 24.3 & 28.7 & 19.6 & 21.4 \\
2005 & 13.0 & 8.4 & 15.4 & 6.2 & 11.3 & 10.9 \\
2006 & 10.5 & 6.4 & 7.5 & 6.4 & 11.9 & 8.6 \\
2007 & -3.2 & 7.0 & 15.6 & 11.9 & 12.1 & 8.6 \\
2008 & -56.7 & -45.6 & -37.0 & -30.0 & -39.5 & -42.1 \\
2009 & 26.3 & 15.2 & 31.9 & 40.0 & 43.4 & 31.3 \\
2010 & 34.4 & 25.6 & 20.3 & 25.1 & 19.6 & 25.1 \\
2011 & 5.5 & 7.5 & 8.5 & 1.2 & 1.6 & 5.0 \\
2012 & 21.3 & 11.1 & 11.0 & 7.5 & 16.4 & 13.5 \\
2013 & 45.2 & 45.2 & 35.7 & 35.9 & 31.8 & 38.8 \\
2014 & 14.8 & 9.2 & 17.1 & 15.3 & 14.9 & 14.3 \\
2015 & 10.4 & 8.9 & 10.1 & 8.6 & 1.9 & 8.1 \\
2016 & 16.3 & 7.7 & 5.4 & 13.8 & 7.9 & 10.2 \\
2017 & 23.8 & 19.8 & 22.0 & 13.6 & 15.9 & 19.0 \\
& & & & & & \\
Total & 420.9 & 327.1 & 582.2 & 587.3 & 521.2 & 492.6 \\
Annual & 11.6 & 10.2 & 13.7 & 13.7 & 12.9 & 12.6 \\
AnnualSTD & 20.7 & 16.9 & 15.2 & 14.6 & 15.8 & 15.8 \\
CV & 1.78 & 1.66 & 1.11 & 1.07 & 1.22 & 1.25 \\
& & & & & &
\end{tabular}

Correlation Matrix

\begin{tabular}{ccccccc}
\hline \multicolumn{1}{c}{$Q 1$} & $Q 2$ & $Q 3$ & $Q 4$ & $Q 5$ & Universe \\
\hline Q1 & 1 & & & & & \\
Q2 & 0.970719 & 1 & & & & \\
Q3 & 0.92857 & 0.948523 & 1 & & & \\
Q4 & 0.890987 & 0.892671 & 0.948386 & 1 & & \\
Q5 & 0.902104 & 0.880684 & 0.952115 & 0.95363 & 1 & \\
Universe & 0.971196 & 0.969266 & 0.983004 & 0.962362 & 0.964908 & 1 \\
\hline
\end{tabular}


Table 3 presents results for Hypothesis Three (OEY), and shows that Hypothesis Three had mixed results. The top quintile OEY had a CV of 1.43 superior to the bottom quintile with a CV of 1.51 . The correlation between the two was +0.81 . However, the top quintile underperformed the universe with a $\mathrm{CV}$ of 1.43 vs. 1.25 with a correlation of +0.94 .

\section{TABLE 3}

OEY

\begin{tabular}{|c|c|c|c|c|c|c|}
\hline \multicolumn{7}{|c|}{ Intermediate Period } \\
\hline Year & Perf & Perf & Perf & Perf & Perf & Perf \\
\hline 2003 & 50.5 & 44.6 & 32.2 & 36.7 & 69.8 & 46.5 \\
\hline 2004 & 37.2 & 28.6 & 14.9 & 19.7 & 6.8 & 21.4 \\
\hline 2005 & 12.0 & 12.0 & 13.5 & 5.7 & 11.0 & 10.9 \\
\hline 2006 & 10.0 & 17.7 & 7.7 & 6.8 & 0.9 & 8.6 \\
\hline 2007 & 3.7 & 5.5 & 8.1 & 10.5 & 15.0 & 8.6 \\
\hline 2008 & -49.5 & -47.0 & -35.0 & -34.4 & -44.1 & -42.1 \\
\hline 2009 & 57.5 & 28.7 & 22.9 & 22.6 & 24.9 & 31.3 \\
\hline 2010 & 27.3 & 22.9 & 21.1 & 24.5 & 29.4 & 25.1 \\
\hline 2011 & 1.6 & 8.6 & 5.6 & 4.6 & 4.2 & 5.0 \\
\hline 2012 & 13.7 & 18.3 & 12.1 & 7.8 & 15.0 & 13.5 \\
\hline 2013 & 37.8 & 35.4 & 31.6 & 46.0 & 43.2 & 38.8 \\
\hline 2014 & 20.4 & 19.7 & 16.3 & 10.2 & 5.0 & 14.3 \\
\hline 2015 & 12.5 & 1.4 & 8.4 & 10.3 & 7.9 & 8.1 \\
\hline 2016 & 13.3 & 19.9 & 8.5 & 2.8 & 6.3 & 10.2 \\
\hline 2017 & 8.3 & 21.5 & 15.7 & 22.9 & 27.2 & 19.0 \\
\hline Total & 606.8 & 566.9 & 378.4 & 416.6 & 454 & 492.6 \\
\hline Annual & 13.9 & 13.5 & 11.0 & 11.6 & 12.1 & 12.6 \\
\hline \multicolumn{7}{|l|}{ Annual } \\
\hline STD & 19.9 & 16.4 & 14.3 & 14.7 & 18.3 & 15.8 \\
\hline $\mathrm{CV}$ & 1.43 & 1.21 & 1.30 & 1.27 & 1.51 & 1.25 \\
\hline \multicolumn{7}{|c|}{ Correlation Matrix } \\
\hline & $Q 1$ & $Q 2$ & $Q 3$ & Q4 & $Q 5$ & Universe \\
\hline Q1 & 1 & & & & & \\
\hline Q2 & 0.919877 & 1 & & & & \\
\hline Q3 & 0.921877 & 0.962214 & 1 & & & \\
\hline Q4 & 0.867032 & 0.90277 & 0.953177 & 1 & & \\
\hline Q5 & 0.81152 & 0.865714 & 0.913839 & 0.92082 & 1 & \\
\hline Universe & 0.944717 & 0.967499 & 0.987259 & 0.963463 & 0.940137 & 1 \\
\hline
\end{tabular}


Table 4 presents the results of Hypothesis Four (EMO), and shows that Hypothesis 4 was confirmed. The top EMO quintile had a CV of 1.21 which was superior to the bottom quintile of 1.56 with a correlation of +0.82 . The top EMO quintile also outperformed the universe with a CV of 1.21 vs 1.25. The correlation was +0.92 .

\section{TABLE 4 \\ EMO}

\begin{tabular}{|c|c|c|c|c|c|c|}
\hline EMO Qui & $\begin{array}{l}\text { tiles } \\
\text { Sector }\end{array}$ & $2^{\text {Sector }}$ & 3 & $\begin{array}{l}\text { Sector } \\
4\end{array}$ & $\begin{array}{l}\text { Sector } \\
5\end{array}$ & Comp Universe \\
\hline Year & Perf & Perf & Perf & Perf & Perf & Perf \\
\hline 2003 & 34.0 & 49.2 & 39.5 & 50.3 & 60.4 & 46.5 \\
\hline 2004 & 20.5 & 25.9 & 21.1 & 17.6 & 21.2 & 21.4 \\
\hline 2005 & 18.8 & 16.5 & 12.2 & 2.1 & 5.2 & 10.9 \\
\hline 2006 & 7.7 & 23.9 & 4.8 & 2.8 & 4.8 & 8.6 \\
\hline 2007 & 26.3 & 10.5 & 6.3 & 4.8 & -3.6 & 8.6 \\
\hline 2008 & -43.2 & -47.1 & -40.7 & -33.6 & -45.9 & -42.1 \\
\hline 2009 & 21.9 & 18.2 & 36.3 & 34.6 & 46.2 & 31.3 \\
\hline 2010 & 29.2 & 25.0 & 21.1 & 22.9 & 26.8 & 25.1 \\
\hline 2011 & 1.8 & 11.0 & 6.6 & 3.8 & 1.8 & 5.0 \\
\hline 2012 & 12.9 & 11.3 & 15.3 & 14.2 & 13.3 & 13.5 \\
\hline 2013 & 46.2 & 38.2 & 35.4 & 31.2 & 42.6 & 38.8 \\
\hline 2014 & 14.2 & 18.0 & 14.4 & 16.9 & 7.8 & 14.3 \\
\hline 2015 & 17.3 & 8.5 & 8.8 & 2.8 & 3.0 & 8.1 \\
\hline 2016 & 6.8 & 12.3 & 9.2 & 7.2 & 15.7 & 10.2 \\
\hline 2017 & 28.7 & 17.0 & 18.9 & 16.0 & 14.7 & 19.0 \\
\hline Total & 620.1 & 571.4 & 455.3 & 396.5 & 402.2 & 492.6 \\
\hline $\begin{array}{l}\text { Annual } \\
\text { Annual }\end{array}$ & 14.1 & 13.5 & 12.1 & 11.3 & 11.4 & 12.6 \\
\hline STD & 17.1 & 16.6 & 15.4 & 15.6 & 17.8 & 15.8 \\
\hline $\mathrm{CV}$ & 1.21 & 1.23 & 1.27 & 1.38 & 1.56 & 1.25 \\
\hline \multicolumn{7}{|c|}{ Correlation Matrix } \\
\hline & $Q 1$ & $Q 2$ & $Q 3$ & $Q 4$ & $Q 5$ & Universe \\
\hline Q1 & 1 & & & & & \\
\hline Q2 & 0.894058 & 1 & & & & \\
\hline Q3 & 0.906778 & 0.920336 & 1 & & & \\
\hline Q4 & 0.834015 & 0.889953 & 0.964105 & 1 & & \\
\hline Q5 & 0.816474 & 0.887692 & 0.964479 & 0.978245 & 1 & \\
\hline Universe & 0.922977 & 0.954456 & 0.989319 & 0.971525 & 0.968927 & 1 \\
\hline
\end{tabular}


Table 5 presents the results of Hypothesis Five (VMO) and shows that Hypothesis 5 had mixed results. The top VMO quintile had a CV of 1.43 vs. the bottom quintile $\mathrm{CV}$ of 1.46 with a correlation of +0.81 . However, the top VMO quintile of 1.43 was inferior to the 1.25 of the universe with a correlation of +0.96 .

TABLE 5

VMO

\begin{tabular}{rrrrrrr}
\hline \multicolumn{1}{l}{$\begin{array}{l}\text { Intermediate Period } \\
\text { Sector 1 }\end{array}$} & \multicolumn{2}{l}{$\begin{array}{l}\text { Sector 2 } \\
\text { Year }\end{array}$} & Perf & \multicolumn{2}{l}{$\begin{array}{l}\text { Sector 3 } \\
\text { Perf }\end{array}$} & \multicolumn{2}{l}{$\begin{array}{l}\text { Sector 4 } \\
\text { Perf }\end{array}$} & \multicolumn{2}{l}{$\begin{array}{l}\text { Sector 5 } \\
\text { Perf }\end{array}$} & \multicolumn{2}{l}{$\begin{array}{l}\text { Comp Universe } \\
\text { Perf }\end{array}$} \\
\hline 2003 & 42.9 & 37.2 & 41.5 & 43.6 & 67.8 & 46.5 \\
2004 & 30.3 & 27.5 & 26.5 & 9.4 & 13.5 & 21.4 \\
2005 & 21.0 & 11.9 & 6.4 & 12.7 & 2.7 & 10.9 \\
2006 & 12.3 & 6.9 & 3.5 & 9.2 & 10.7 & 8.6 \\
2007 & 11.0 & 18.6 & 8.5 & 5.0 & -0.1 & 8.6 \\
2008 & -51.8 & -43.0 & -38.7 & -41.4 & -35.8 & -42.1 \\
2009 & 20.3 & 18.1 & 33.8 & 41.2 & 44.2 & 31.3 \\
2010 & 28.8 & 23.3 & 23.7 & 28.9 & 20.4 & 25.1 \\
2011 & 8.2 & 6.8 & 9.1 & 3.6 & -2.8 & 5.0 \\
2012 & 10.4 & 22.6 & 11.8 & 9.0 & 13.6 & 13.5 \\
2013 & 36.0 & 39.9 & 39.3 & 35.8 & 42.7 & 38.8 \\
2014 & 19.4 & 18.2 & 16.6 & 9.8 & 7.5 & 14.3 \\
2015 & 12.4 & 9.9 & 11.2 & 10.1 & -2.9 & 8.1 \\
2016 & 10.9 & 8.2 & 9.6 & 12.5 & 9.7 & 10.2 \\
2017 & 22.2 & 19.9 & 16.4 & 22.9 & 13.7 & 19.0
\end{tabular}

Total Cumulative for Intermediate Periods

\begin{tabular}{|c|c|c|c|c|c|c|}
\hline & Sector 1 & Sector 2 & Sector 3 & Sector 4 & Sector 5 & Comp Universe \\
\hline & Perf & Perf & Perf & Perf & Perf & Perf \\
\hline Total & 520.7 & 535.7 & 510.1 & 456.0 & 395.0 & 492.6 \\
\hline Annual & 12.9 & 13.1 & 12.8 & 12.1 & 11.3 & 12.6 \\
\hline Annual STL & 18.5 & 16.1 & 15.4 & 16.2 & 16.5 & 15.8 \\
\hline $\mathrm{CV}$ & 1.43 & 1.23 & 1.20 & 1.34 & 1.46 & 1.25 \\
\hline
\end{tabular}

Correlation Matrix

\begin{tabular}{lrrrrrr}
\hline & $Q 1$ & \multicolumn{1}{c}{$Q 2$} & $Q 3$ & $Q 4$ & $Q 5$ & Universe \\
\hline Q1 & 1 & & & & & \\
Q2 & 0.962173 & & & & & \\
Q3 & 0.941433 & 0.944005 & 1 & & & \\
Q4 & 0.902941 & 0.869911 & 0.945035 & 1 & & \\
Q5 & 0.810528 & 0.81018 & 0.90617 & 0.925821 & 1 & \\
Universe & 0.959387 & 0.952318 & 0.985823 & 0.968752 & 0.932811 & 1 \\
\hline
\end{tabular}




\section{CONCLUSION}

This study examined the semi-strong form of the EMH utilizing key elements of the Security Market Line. Specifically, this study examined the value of a unique CAPM equation: Alpha minus Beta. Sectoring the S\&P 1500 based on this statistic resulted in the top quintile outperforming the universe. This results in a portfolio that could well be developed into a smart beta construct. A few single factors were analyzed in the top quintile portfolio. Only EMO, Earnings Momentum, produced a marginally superior result against its universe. Please note the term factor. The ALP-BTA study only utilized one factor while most smart beta portfolios have multiple factors involved in the selection of stocks.

\section{REFERENCES}

Armenc, N., Goltz, F., \& Lodh, A. (2012). Choose Your Betas: Benchmarking Alternative Equity Index Strategies. Journal of Portfolio Management, 39(1), 72-88.

Basu, S. (1997, June). Investment Performance of Common Stocks in Relation to Their Price-Earnings Ratio: A Test of the Efficient Market Hypothesis. Journal of Finance, 663-687.

Chan, L., Hamao, Y., \& Lakonishok. (1991). Fundamentals of Stock Returns. Journal of Finance.

Chow, T., Hsu, J., Kalesnik, V., \& Little, B. (2011). A Survey of Alternative Equity Index Strategies. Financial Analyst's Journal, 67(5), 37-57.

Christensen, C. M. (1997). The Investors Dilemma. Harvard University Press.

Clark, R., Silva, H., \& Thorley, S. (2011). Minimum Variance Portfolio Composition. Journal of Portfolio Management, 37(2), 31-45.

Cohen, L., \& Frazzini, A. (2008). Economic links and predictable returns. The Journal of Finance, 63, $1977-2011$.

Fama, E. (1970, May). Efficient Capital Markets: A Review of Theory and Empirical Work. Journal of Finance.

Fama, E., \& French, K. (1992, June). The Cross Section of Expected Stock Returns. Journal of Finance, 427-465.

Fama, E., \& French, K. (2016). Dissecting anomalies with a five factor model. Review of Financial Studies, 29(1), 69-103.

Ford Equity Research Hyper Investment Program. (n.d.). Ford Equity Research, San Diego. California.

Fuller, R., Han, B., \& Tung, Y. (2010). Thinking about Indices and "Passive" versus Active Management. Journal of Portfolio Management, Summer, 34(4), 35-47.

Graham, B., \& Dodd \& Cottle. (1962). Security Analysis, $4^{\text {th }}$ Edition. McGraw-Hill Book Company, New York, New York.

Grinold, R., \& Kane, R. R. (1995). Active Portfolio Management. Probus Publishing Company, Chicago, Illinois.

Haugen, R. A. (1999). The Inefficient Stock Market. Prentice-Hall, Upper Saddle River, New Jersey.

Haugen, R. A. (1999). The New Finance: The Case Against Efficient Markets, $2^{\text {nd }}$ Edition. Prentice-Hall. Upper Saddle River, New Jersey

Hirshleiferm, D., Lim, S. S., \& Teoh, S. (2007). Driven to distraction: extraneous events and under reaction to earnings news. Journal of Finance.

Jegadeesh, N., \& Titman, S. (1993, March). Returns to Buying Winners and Selling Losers: Implications for Stock Market Efficiency. Journal of Finance.

Kahn, R., \& Lemmon, M. (2015). Smart Beta: The Owner's Manual. Journal of Portfolio Management, 41(2).

Kahn, R., \& Lemmon, M. (2016, January/February). The Asset's Manager's Dilemma: How Smart Beta is Disrupting the Investment Management Industry. Financial Analysts Journal, 72(1).

Lakonishokm J., Shleifer, A., \& Vishay, R. (1994, December). Contrarian Investment, Extrapolation, and Risk. Journal of Finance. 
Minami, S., \& Wakatsuki, T. (2014, May 9). Alpha Minus Beta: Simple Rule for Smart Beta Strategy. Retrieved from

SSRN: https://ssrn.com/abstract=2435729 or http://dx.doi.org/10.2139/ssrn.2435729

Oppenheimer, H., \& Schlarbaum, O. (1981, September). Investing with Benjamin Graham: An Ex-Ante Test of the Efficient Market Hypothesis. Journal of Financial and Quantitative Analysis.

Rosenbaum, B., \& Guy, J. (1976, May-June and July-August). Predication of Beta from Investment Fundamentals. Part One and Part Two, Financial Analyst's Journal.

Schwab, C. (2018, February 16). Smart Beta Strategies: Understanding Key Differences. Center for Financial Research.

Scientific Beta. (2018, February). Robustness of Smart Beta Strategies.

Williams, J. B. (1938). The Theory of Investment Value. Harvard University Press, Cambridge, Mass. 